There is another problem discussed by Bulmer, that of mirror imaging, which deserves to be kept in mind. If we agree that left-handedness and situs inversus of the viscera occur no more frequently than by chance in oneegg twins there remains the question of whether we assign the difference to heredity or to environment. Surely to neither. It is the effect of an uncertainty in development. It resembles that primary uncertainty in the position of partner chromosomes at meiosis which underlies the almost universal uncertainty in frequency of crossing-over. But it differs inasmuch as it seems to lie close to the limit of selectable variation.

When all these questions have been considered we may return to ask ourselves where we stand with the classical assumption that one-egg twins are genetically identical and their discordances assignable to the " environment". It seems we have to withdraw this assumption and replace it with the principle that their discordance gives us a maximum estimate, and statistically always an over-estimate of environmental influence. If we are to assess the value of such tests as those of intelligence or of susceptibility to tuberculosis which are quoted by Bulmer, this, I suggest, is what matters most.

\title{
REFERENGES
}

BRuins, J. w. 1963. Discordant mongolism in monozygotic twins. Proc. 11 Int. Congr. Genet., 1,307 .

BULmer, M. G. 1970. The Biology of Twinning in Man. Clarendon Press, Oxford.

DARLINoton, C. D. 1954. Heredity and environment. Caryologia, Supplement to Vol. VI, 370-381.

DARLINGton, C. D. 1969. Mosaics, twins and inter sexes. Nature, 223, 328-329.

DEKABAN, A. 1966. Twins, probably monozygotic: one mongoloid with 48 chromosomes, the other normal. Cytogenetics, 4, 227-239.

EDWARds, J. H. 1968. The value of twins in genetic studies. Proc. R. Soc. Med., 61.

EDWARDs, J. H., et al. 1966. Monozygotic twins of different sex. F. Med. Genet., 3, 77-158. LIEBENAM, t. 1938. Zwillingspathologische untersuchungen u.s.w. Z. mensch. Vererb. u. Konstl., 22, 373-417.

PRICE, BRONSON. 1950. Primary biases in twin studies: are view of prenatal and natal difference-producing factors in monozygotic pairs. Am. F. Hum. Genet., 2, 293-352.

RIFE, D. C. 1952. Twins and research. Acta Genet. Med. Gemell., 1, 14-23.

STERN, C. 1968. Genetic Mosaics and Other Essays. Harvard U.P., Cambridge, Mass; Oxford U.P., London.

UCHIDA, I. A., AND ROWE, R. D. 1957. Discordant heart anomalies in (one-egg) twins. Am. $\mathcal{F}$. Hum. Genet., 9, 133-140.

WALKER, N. F. 1950. Discordant monozygotic twins (A) with retinoblastoma and (B) cleft palate. Am. F. Hum. Genet., 2, 375-384.

\section{STUDIES ON THE RNA OF THE MATE-KILLER PARTICLES OF PARAMECIUM}

RAY BAKER

School of Biological Sciences, University of East Anglia, Norwich

Received 27.v.70

\section{Introduction}

KILLeR particles were discovered originally as cytoplasmically inherited factors responsible for the killing activity of certain stocks of Paramecium aurelia (Sonneborn, 1943). They were shown to require the presence of a 
nuclear gene, or genes, for their maintenance and replication. They were later visualised in the cytoplasm (Preer, 1950). Light microscopy revealed that they had the size and shape of bacteria, and they occurred in numbers from 100 to 1000 per cell, depending on the type of particle. Studies with the electron microscope showed that they consist of a double membrane and granular internal contents (Jurand and Preer, 1968; Beale and Jurand, 1960). These granules were approximately the size of ribosomes (Jurand and Preer, 1968).

Biochemically the particles have certain features which distinguish them from other components of the cell. For example the mate-killer particles of stock 540, syngen 1 , have diaminopimelic acid in the cell wall (Stevenson, 1967), although they may acquire this from the bacteria on which the Paramecium are fed rather than synthesise it themselves.

There are reports, using biochemical techniques that isolated particles contain RNA, DNA and protein (van Wagtendonk and Tanquay, 1963; Stevenson, 1969). These macromolecules have been reported to be present in situ, using cytochemical techniques (Beale and Jurand, 1960). Also, specific enzymes have been shown to be present in isolated particles, e.g. DNA-dependent RNA polymerase (Stevenson, 1969), and Kreb's cycle enzymes (Kung, 1968). However, full characterisation of these macromolecules has not been reported.

Some particles can be grown, in complex medium, outside the host cell (van Wagtendonk, Clark and Godoy, 1963; Williams, unpublished). However, they grow slowly and to a low population density (Williams, unpublished). There are a number of possibilities to explain this failure to grow well.

We have undertaken a biochemical study of the killer particles in the hope of understanding their interaction with the host cell. Here we report on an analysis of the RNA extracted from purified mate-killer particles, on the synthesis of these macromolecules and their molecular weights.

\section{MATERIALS AND METHODS}

\section{Growth of Paramecia and preparation of mu particles}

Cells of stock 540 bearing mu particles were grown in grass infusion inoculated with Aerobacter aerogenes. Usually 25 litres were grown for about ten days to reach starvation. The cells were harvested in an Alfa-Laval cream separator followed by centrifugation at approx. $550 \times g$ in an oiltesting centrifuge. To prepare killer particles, homogenisation of Paramecia was carried out in an MSE overhead homogeniser. The particles were purified by passage through a column of cellex-P (Bio-Rad Cation exchange cellulose) in $0.01 \mathrm{M}$ phosphate buffer, $p \mathrm{H} 6 \cdot 8$, at room temperature, followed by centrifugation through a discontinuous Ficoll gradient $(10,20,30$, 40 per cent.). The mu particles appeared as a band in the lower part of the 20 per cent. region of the gradient. This fraction of the gradient was then pipetted off and centrifuged at $25,000 \times \mathrm{g}$ for $10 \mathrm{~min}$. to sediment the particles. The total number of particles obtained is usually about $4 \times 10^{10}$. Viable counts of mu preparations on nutrient agar plates were less than 2 per cent. of the total number of particles obtained. Mu particles do not form colonies on nutrient agar following in vitro growth (Williams, unpublished). 


\section{Preparation and analysis of $R \mathcal{N} A$}

RNA was made from whole cell preparations and mu particles by the following method.

After freeze-thawing the mu particle and whole cell preparation, the sample was ground in liquid nitrogen, and treated with 2.5 per cent. sodium lauryl sulphate at $60^{\circ} \mathrm{C}$. RNA was extracted using $p$-amino salicylate and phenol- $m$-cresol (Kirby, 1965). The RNA was analysed by electrophoresis on 2.5 per cent. polyacrylamide gels (Loening, 1967), usually for $2 \frac{1}{2}-3$ hours at $5 \mathrm{~mA}$./gel. The gels were scanned on a Joyce-Loebl chromoscan.

\section{Results AND DISCUSSION}

\section{Electrophoresis of RNA from mu particles and Paramecia}

In fig. 1 (a) the RNA from mu particles shows two high molecular weight peaks (II and IV) characteristic of ribosomal RNA, and an RNA peak of lower molecular weight (V) which could consist of transfer, " $5 \mathrm{~S}$ " and/or degradation products. The ratio of the two high molecular weight peaks of mu RNA is approximately $1: 1$ whereas normally the ratio of the two ribosomal RNA peaks is $2: 1$ in most organisms (see fig. 1). This could reflect a real situation in the cell, differential extraction, or degradation. When $E$. coli and mu RNA preparations were mixed and run together on a single gel, only two high molecular weight peaks were observed, as well as the lower molecular weight peak. When stock 540 without mu was used and carried through the same procedure for preparing mu particles, no RNA peaks were extractable from the material present on the Ficoll gradient in the region where mu usually appear. When mu and Paramecium RNA (the latter prepared from whole cells of stock 540, particle free, grown axenically) were run together on a gel, four high molecular weight peaks were seen (I, II, III and IV-see fig. I (b)). RNA prepared from stock 540 without mu particles only shows two high molecular weight peaks (I and III - see fig. $1(c)$ ).

These results (fig. $1(a)$ and $(b))$ suggest that there are distinct species of RNA associated with the mu particles. The high molecular weight RNA behaves on these gels like ribosomal RNA, and has the same molecular weight as that from E. coli $\left(1 \cdot 1 \times 10^{6}\right.$ and $\left.0.55 \times 10^{6}\right)$ (Bolton, 1966). In terms of sedimentation constant then the two species would be 23S and 16S.

By the criterion of size of RNA molecules the mu particles are distinguished from certain types of intracellular parasites, such as those responsible for trachoma and psittacosis disease, which have been reported as having high molecular weight RNA's of $16 \mathrm{~S}$ and 21S (Sarov and Becker, 1968). This could also distinguish mu particles from mycoplasma organisms, if the latter have RNA species of $16 \mathrm{~S}$ and 22S, as has been reported (Razin, 1969). Furthermore, mitochondrial RNA in the related protozoan Tetrahymena has been recorded as 18S and 14S (Suyama, 1967). These RNA molecules were probably degradation products.

The major RNA components of Paramecium seen in the RNA extracted from cells without particles (fig. $1(c)$ ) are 25S (M.W. $1.30 \times 10^{6}$ ) and $18 \mathrm{~S}$ (M.W. $\left.0.66 \times 10^{8}\right)$. These figures are in agreement with those of other workers (Reisner, Rowe and MacIndoe, 1968).

These results presented here show that the mu particle has ribosomal RNA molecules similar to a free-living bacterium, i.e. 23S and I6S. 

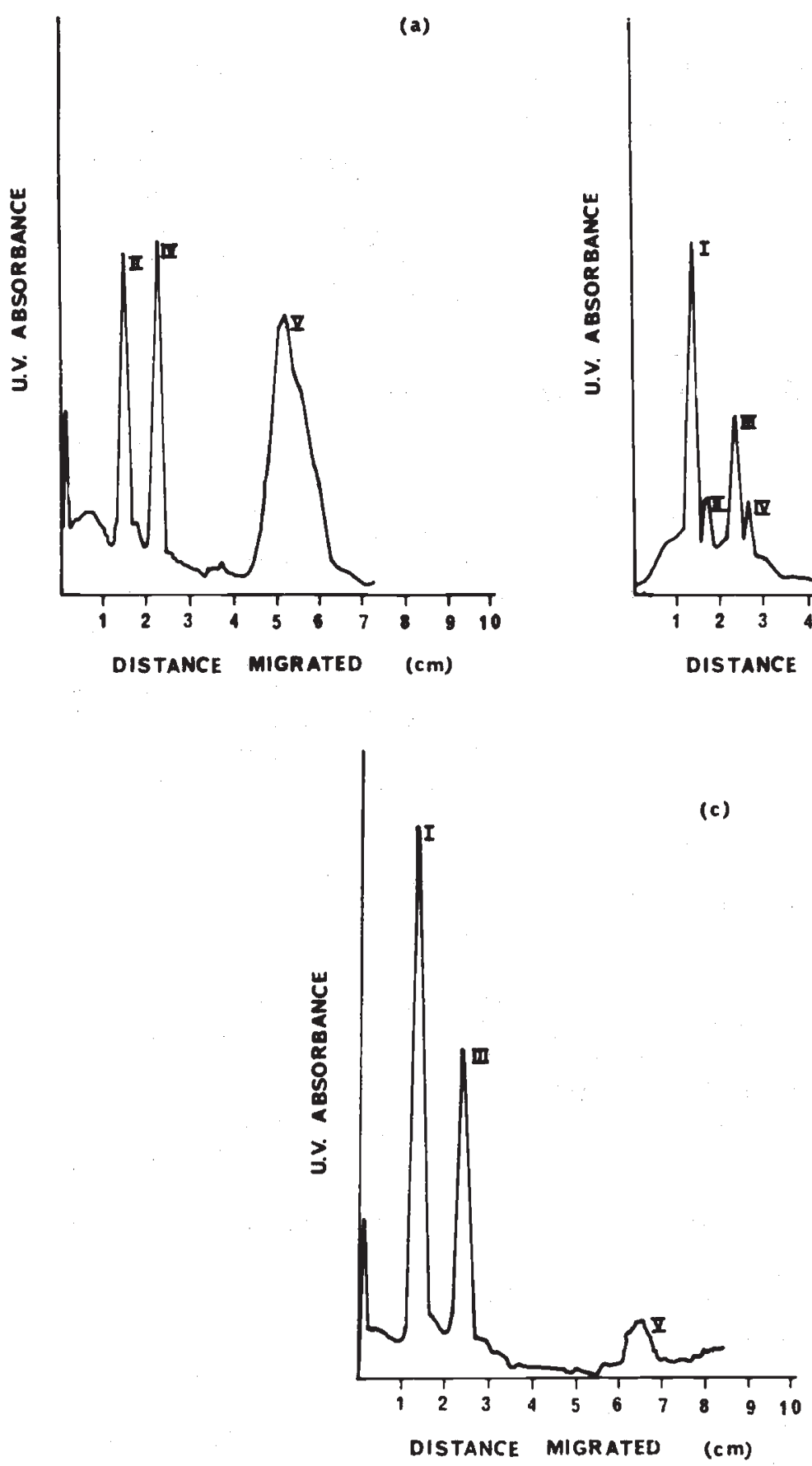

Frg. 1.-Sucrose was added to the RNA preparations to increase the density and facilitate layering. Usually 30-40 $\mu \mathrm{g}$ RNA were layered on to the gels. Molecular weights were determined from the relationship: distance migrated is proportional to log molecular weight. (a) Mu RNA (b) Mu+Paramecium RNA (c) Paramecium RNA. 


\section{Labelling of $R \mathcal{N} A$ of mu particles followed by gel electrophoresis}

In order to show the presence of any other RNA species, e.g. rapidly labelled species ("messenger" RNA) in mu particles, paramecia have been labelled with ${ }^{3} \mathrm{H}$-uridine, by adding isotope $(50 \mu \mathrm{Ci} / \mathrm{l})$ to the growth medium at the time of inoculation with cells ("steady state" label). In another experiment the isotope was added 24 hours ("pulse" label) before harvesting the cells. In both experiments the harvesting was carried out after ten days of growth. The time of labelling was chosen in relation to the observation that particles divide once every 24 hours in vitro (Williams, unpublished). The fission rate in starved cells is unknown.

RNA was extracted from purified mu particles, and run on gels, which were scanned as before. These were then frozen in dry ice and cut in a gel-slicer. The slices were dissolved in hydrogen peroxide (Young and Fulhurst, 1965), and counted in Bray's solution, in a Packard Tri-Carb scintillation counter.

The radioactivity distribution on the gels shows no great difference between the two experiments except for a large peak of labelled material in the low molecular weight region with the one-day labelled sample. This could be due to rapid degradation of newly labelled RNA during isolation. Nevertheless, the high molecular weight RNA of mu is labelled at a late stage in the growth of the cells in this medium. There is no evidence in the RNA of mu particles for the heterogeneous species of RNA often called messenger, but shorter periods of labelling may be needed to detect such species.

It remains to be seen if the high molecular weight RNA of mu particles is synthesised from the DNA of the particles or the host cell nucleus, or both. It is probable that the RNA is organised into typical bacterial ribosomes, and that these function normally in protein synthesis. However, it remains a possibility that the products of host nuclear genes migrate to the particle and are involved in the synthesis of certain proteins. Also the products of mu particle gene action may migrate to the cytoplasm of the host cell.

These experiments give credence to the idea that the mate-killer particles were once free-living bacteria. However, in becoming adapted to the cytoplasm of Paramecium they required the presence of a nuclear gene of Paramecium (Gibson and Beale, 1961) and also have a much slower replication rate than that normally associated with free-living bacteria (Williams, unpublished).

\section{Summary}

1. Mate-killer particles (mu) from stock 540 syngen 1 of Paramecium aurelia contain ribosomal RNA molecules of the same molecular weight as those of bacteria.

2. The ribosomal RNA molecules of the particles differ in molecular weight from those of the Paramecium host.

3. There was no evidence for rapidly labelled RNA in the particles with 1-day labelling periods of whole cells.

4. The results suggest a close evolutionary relationship between matekiller particles and free-living bacteria. 
Acknowledgments. - Thanks are due to the Medical Research Council for the award of a post-graduate studentship, to Mr Norman Martin for technical assistance and to Dr I. Gibson for advice.

\title{
5. REFERENGES
}

BEALE, G. H., AND JURAND, A. 1960. Structure of the mate-killer (mu) particles in Paramecium aurelia, stock 540. J. Gen. Microbiol., 23, 243-252.

BolTon, E. T. 1966. The isolation and properties of the two high molecular weight fractions of E. coli ribosomal RNA. In Procedures in Nucleic Acid Research (ed. G. L. Cantoni and D. R. Davies), 437-443. Harper \& Row.

GIBSON, I., AND BEALE, G. H. 1961. Genic basis of the mate-killer trait in Paramecium aurelia, stock 540. Genetical Res., 2, 82-91.

JURAND, A., AND PREER, L. B. 1968. Ultrastructure of flagellated lambda symbionts in Paramecium aurelia. 7. Gen. Microbiol., 54, 359-364.

KIRBY, K. s. 1965. Isolation and characterisation of ribosomal ribonucleic acid. Biochem. $\mathcal{G}$., 96, 266-269.

Kung, c. 1968. Oxidative Metabolism of Kappa Particles from Paramecium aurelia, Stock 51 in relation to their nature and origin. Ph.D. Thesis, University of Pennsylvania.

LOENING, $v$. 1967. The fractionation of high molecular weight ribonucleic acid by polyacrylamide-gel electrophoresis. Biochem. F., 102, 251-257.

PREER, JR., J. R. 1950. Microscopically visible bodies in the cytoplasm of the "killer" strains of $P$. aurelia. Genetics, 35, 344-362.

RAzIN, s. 1969. Structure and function in Mycoplasma. Ann. Rev. Microbiol., 23, 317-356.

REISNER, A. H., ROWE, J., AND MACINDOE, J. 1968. Structural studies on the ribosomes of Paramecium: evidence for a "primitive" animal ribosome. J. Mol. Biol., 32, 587-610.

SAROV, J., AND BECKER, Y. 1968. RNA in the elementary bodies of trachoma agent. Nature, $217,849-852$.

SONNEBORN, T. M. 1943. Gene and cytoplasm. I. The determination and inheritance of the killer character in variety 4 of $P$. aurelia. II. The bearing of determination and inheritance of characters in $P$. aurelia on problems of cytoplasmic inheritance, pneumococcus transformations, mutations and development. Proc. U.S. Nat. Acad. Sci. (Wash.), 29, 329-343.

STEVenson, 1. 1967. Diaminopimelic acid in the mu particles of Paramecium aurelia. Nature, $215,434-435$.

stevenson, 1. 1969. The biochemical status of $\mu$ particles in Paramecium aurelia. J. Gen. Microbiol., 57, 61-75.

sUYama, Y. 1967. The origins of mitochondrial ribonucleic acids in Tetrahymena pyriformis. Biochemistry, 6, 2829-2839.

van WAgtendonk, W. J., Clark, J. A. D., AND Godoy, G. A. 1963. The biological status of lambda and related particles in Paramecium aurelia. Proc. U.S. Acad. Sci. (Wash.), 50, 835-838.

VAN WAGTENDonk, W. J., AND TANQUAY, R. B. 1963. The clremical composition of lambda in Paramecium aurelia, stock 299. F. Gen. Microbiol., 33, 395-400.

YOUNG, R. W., AND FULhURST, H. W. 1965 . Recovery of $S^{35}$ radioactivity from proteinbearing polyacrylamide gel. Analyt. Biochem., 11, 389-391.

\section{PARALLEL POLYMORPHISM FOR SUPERNUMERARY SEGMENTS IN CHORTHIPPUS PARALLELUS \\ V. A NEW POLYMORPHISM IN EUROPE}

\author{
M. WESTERMAN \\ Department of Genetics, University of Birmingham*
}

Received 4.vi.70

\section{Introduction}

POLYMORPHISMS for supernumerary segments on the smaller members of the chromosome complement are well known in the Acrididae (White, 1954).

* Present address : Genetics Department, La Trobe University, Melbourne, Australia. 